\title{
Microwave-assisted acid Digestion Procedure for Trace Elements Determination in Polychaete Chaetopterus variopedatus
}

\author{
Eça, G. F.; Brito, G. B.; Barbosa, I. S.; Korn, M. G. A.; Hatje, V.*
}

Rev. Virtual Quim., 2014, 6 (4), 1047-1061. Data de publicação na Web: 4 de maio de 2014

\author{
http://www.uff.br/rvq
}

\section{Procedimento de Digestão Assistido por Micro-ondas para Determinação de Elementos-traços no Poliqueta Chaetopterus variopedatus}

Resumo: Este estudo avaliou e aplicou uma digestão, com ácido diluído, assistida por micro-ondas para determinar elementos-traço ( $\mathrm{As}, \mathrm{Ba}, \mathrm{Cd}, \mathrm{Co}, \mathrm{Cr}, \mathrm{Cu}, \mathrm{Hg}, \mathrm{Mn}, \mathrm{Ni}$ e $\mathrm{Sb}$ ) em amostras de poliquetas (Chaetopterus variopedatus). Após a otimização do método, empregando-se material certificado de referência (1566b CRM, tecido Oyster), os analitos foram determinados por espectrometria de massas com plasma indutivamente acoplado (ICP-MS) e espectrometria de emissão atômica com plasma indutivamente acoplado (ICP OES). A repetibilidade foi adequada $(<10 \%)$, os resultados obtidos com o CRM concordaram com os valores certificados e o teor de carbono residual valores (RCC) foi menor do que $15 \%$. Além disso, até dez amostras podem ser simultaneamente decompostas em 34 min., resultando num elevado rendimento. O método desenvolvido foi aplicado em amostras de poliquetas coletados na Baía de Todos os Santos, Bahia, Brasil.

Palavras-chave: Elementos-traço; digestão assistida por micro-ondas; ácidos diluidos; tecido de poliquetas.

\begin{abstract}
This study evaluated and applied a microwave-assisted diluted acid digestion to determine trace elements ( $\mathrm{As}, \mathrm{Ba}, \mathrm{Cd}, \mathrm{Co}, \mathrm{Cr}, \mathrm{Cu}, \mathrm{Hg}, \mathrm{Mn}, \mathrm{Ni}$ and $\mathrm{Sb}$ ) in polychaete (Chaetopterus variopedatus) samples. After the optimization of the method with certified reference material (CRM 1566b, Oyster tissue), the analytes were determined by inductively coupled plasma mass spectrometry (ICP-MS) and inductively coupled plasma optical emission spectrometry (ICP OES). Repeatability was adequate $(<10 \%)$, results for CRM agreed with the certified values and the residual carbon content (RCC) values were lower than $15 \%$. Moreover, up to ten samples can be simultaneously decomposed in $34 \mathrm{~min}$., resulting in a high sample throughput. The developed method was applied to polychaete samples collected from Todos os Santos Bay, Bahia, Brazil.
\end{abstract}

Keywords: Trace element; microwave-assisted digestion; dilute acid mixture; polychaete tissue.

\footnotetext{
* Universidade Federal da Bahia, Instituto de Química, Campus of Ondina, Salvador, Bahia, CEP 40170115, Brazil. Tel.: +55 713283-5648.

Mvanessahatje@gmail.com; vanessa@pq.cnpq.br DOI: $10.5935 / 1984-6835.20140066$
} 


\title{
Microwave-Assisted Acid Digestion Procedure for Trace Elements Determination in Polychaete Chaetopterus variopedatus
}

\author{
Gimara F. Eça, ${ }^{a, b}$ Geysa B. Brito, ${ }^{b}$ Isa S. Barbosa, ${ }^{b}$ Maria G. A. Korn, ${ }^{b}$ \\ Vanessa Hatje ${ }^{\mathrm{a}, \mathrm{b}, *}$ \\ ${ }^{a}$ CIENAM, INCT de Energia e Ambiente, Salvador, Bahia, Brazil.

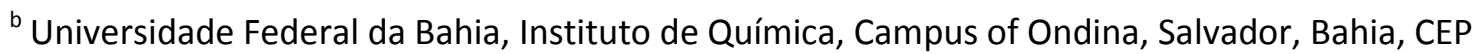 \\ 40170-115, Brazil. \\ *vanessahatje@gmail.com; vanessa@pq.cnpq.br
}

Recebido em 6 de fevereiro de 2014. Aceito para publicação em 27 de março de 2014

\section{Introduction}

\section{Experimental}

2.1. Study area and sample collection

2.2. Instrumentation

2.3. Reagents and solutions

2.4. Optimization of sample digestion

2.5. Determination of the acidity and residual carbon content (RCC) of the digests

2.6. Quality assurance and quality control

\section{Results and discussion}

3.1. Techniques performance

3.2. Quality assurance and quality control

3.3. Optimization of the sample digestion procedure

3.4. Effect of the sample size on the efficiency of the microwave-assisted digestion process

3.5. Applications

\section{Conclusions}

\section{Introduction}

Many species of marine invertebrates, such as clams, mussels and polychaete worms are known to accumulate trace metals in their tissues and are therefore widely used in environmental monitoring programs. Accumulated metal concentrations provide a relative measure of the total metal intake of an organism, including all routes, integrated over its life time. ${ }^{1-3}$ Marine invertebrates, such as polychaete, have an important role in the transfer of metal from prey to predators 
(e.g. crustaceans and fish). ${ }^{4}$ At the same time, bivalves and fish represent a major part of the human diet, especially for coastal populations, which are more susceptible to the toxic effects that elevated metal concentrations may pose to marine shellfish and fish. ${ }^{5}$

Several analytical techniques are available for the determination of trace elements in polychaetes, such as inductively coupled plasma optical emission spectrometry (ICP $\mathrm{OES})_{,}^{6,7}$ inductively coupled plasma-mass spectrometry (ICP-MS), ${ }^{8}$ flame atomic absorption spectrometry (FAAS) and electrothermal-atomic absorption spectrometry (ETAAS). ${ }^{9,10}$ However, it is usually necessary to convert the solid sample to a solution which represents the original material. Several procedures have been developed in order to shorten analysis time and also to minimize the problems associated with solid sample pre-treatment, such as sample contamination and analyte loss. Microwave-assisted digestion procedures using closed vessels and various acid mixtures have been employed to destroy the organic matrix of the biological samples, rapidly at elevated temperatures and/or pressure, to accelerate sample digestion and to minimize contamination and losses of volatile elements. ${ }^{11-13}$ Multiple combinations of acid mixtures $\left(\mathrm{HNO}_{3}, \mathrm{HNO}_{3}-\mathrm{HCl}, \mathrm{HNO}_{3}-\right.$ $\mathrm{H}_{2} \mathrm{O}_{2}, \mathrm{HNO}_{3}-\mathrm{HF}, \mathrm{HNO}_{3}-\mathrm{HCl}-\mathrm{H}_{2} \mathrm{O}_{2}, \mathrm{HNO}_{3}-\mathrm{H}_{2} \mathrm{SO}_{4}$ ) have been reported in the literature for the digestion of environmental samples using microwave energy. ${ }^{13-18}$ For polychaetes tissues is required to do a total digestion to obtain reliable results. ${ }^{19,20}$ The use of diluted solutions is recommended, once it strongly minimize the generation of acid residues, which is in accordance to green chemistry recommendations. ${ }^{20-28}$

The effect of the concentrations of nitric acid and hydrogen peroxide, largely used in biological tissues digestions, on closed vessel microwave-assisted systems, was previously described. $^{20} \mathrm{~A}$ closed vessel microwaveassisted procedure combined with diluted nitric acid solution $\left(7 \mathrm{~mol} \mathrm{~L}^{-1}\right.$ of $\left.\mathrm{HNO}_{3}\right)$ for digestion of soybeans grains, bovine blood, bovine muscle and bovine viscera obtained residual carbon content (RCC) of $16 \%$ and good recoveries. The RCC and standard deviation were smaller than those obtained with digestions using concentrated $\mathrm{HNO}_{3}{ }^{29}$ The efficiency of diluted nitric acid for the oxidation of organic matter can be explained by the regeneration of nitric acid promoted by the combination of the nitrogen oxide species with the oxygen present inside the reaction vessel. ${ }^{25,29}$ Bizzi and colleagues ${ }^{26}$ reported the efficiency of diluted nitric acid solutions combined with oxygen gas for microwave-assisted digestion of bovine liver and non-fat milk powders samples. ${ }^{27}$ The experimental data suggested that the regeneration of $\mathrm{HNO}_{3}$ could be explained by the oxygen atmosphere that improved the effectiveness of digestion using diluted nitric acid solutions. ${ }^{28,30}$

The main purpose of this study was to develop a microwave-assisted digestion procedure, using diluted acid for the determination of trace elements in polychaete (Chaetopterus variopedatus). There is little information on the content of trace elements in the $C$. variopedatus polychaete. $^{31}$ This is a cosmopolitan polychaete specie occurring in several shallow coastal habitats, from temperate to tropical locations worldwide. ${ }^{32,33}$ In the Brazil, this specie occurs from the Northeast (Alagoas State) to the South (Rio Grande do Sul). ${ }^{34}$ The procedure was chosen by selecting the best analytical conditions from several experiments to provide suitable recoveries of elements from certified reference material. The developed method was then applied to the trace elements measurement in $C$. variopedatus, collected at the Todos os Santos Bay, Bahia, Brazil.

\section{Experimental}

\subsection{Study area and collection}

The BTS is the second largest bay in Brazil, with an area of $1,223 \mathrm{~km}^{2}$ and an average 
depth of $9.8 \mathrm{~m}$. The climate of this region is tropical humid, with average temperature of $25.3{ }^{\circ} \mathrm{C}$ and average annual rainfall of 1,002 $\mathrm{mm} .{ }^{35}$ Polychaete Chaetopterus variopedatus were collected at Maré (Praia Grande and Botelho) and Bimbarras islands and Itapagipe Bay, Todos os Santos Bay, Bahia, Brazil (Figure 1). The sampling points were selected based on the occurrence of this species in the
BTS, in areas subject to anthropogenic activities. The $C$. variopedatus are small organisms that live in an upright u-shaped tube, lined with mucous, that they construct in unconsolidated sediments. Although the tubes can be relatively large $(40 \mathrm{~cm})$, the organisms collected measured only about 15 $\mathrm{cm}$ (Figure 2).

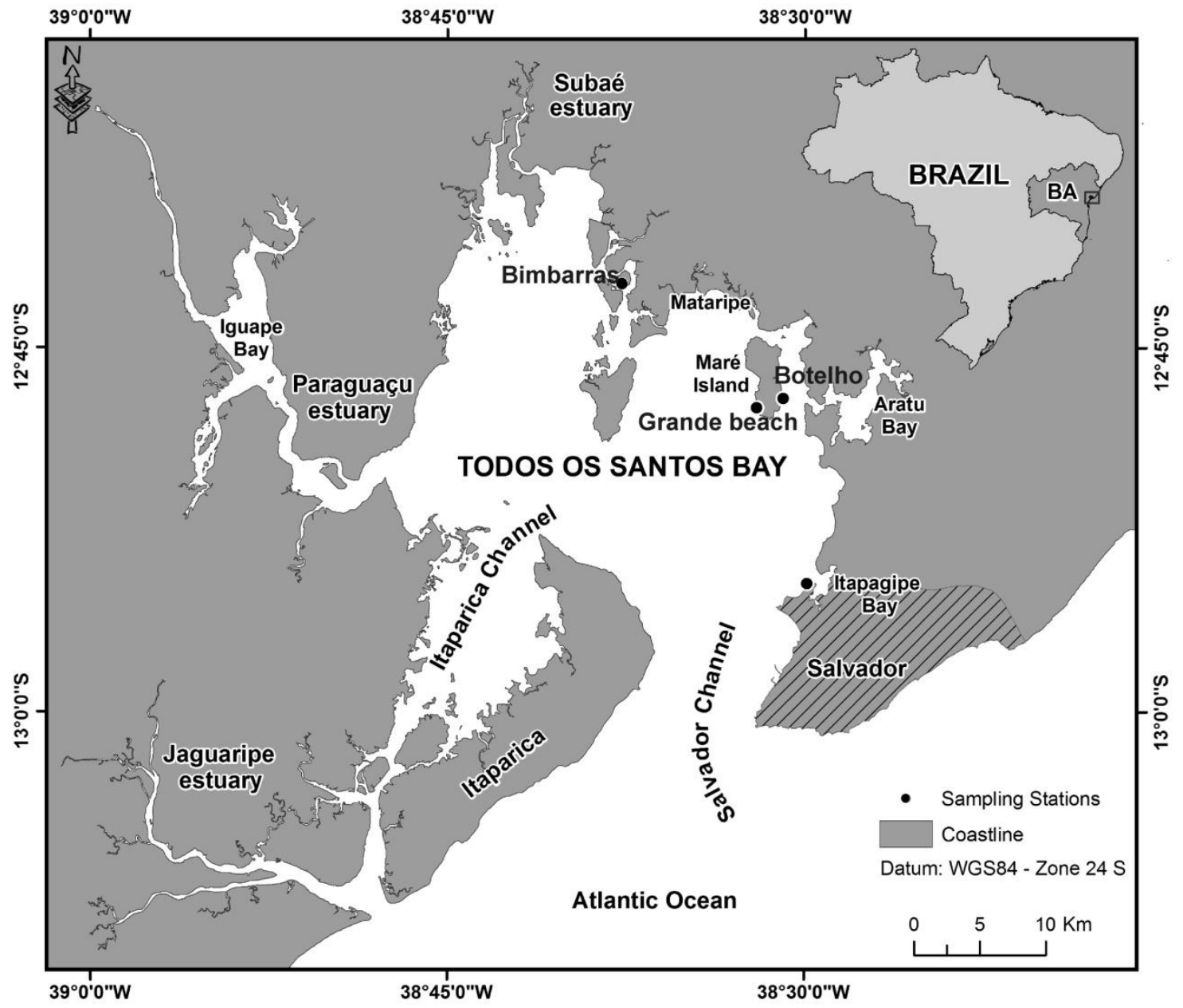

Figure 1. Study area showing the location $(\bullet)$ of polychaete sampling sites at the Todos os Santos Bay, Bahia

In each site, a minimum of 15 polychaetes were collected and combined in one composite sample. In the field, organisms were washed with seawater to remove encrustations and excess of sediment and placed in decontaminated plastic vessels with seawater to purge their intestines. The intestines were then removed using a plastic spoon and the polychaetes were rinsed with ultrapure water. The biological tissues were freeze dried (Alfa 1-4 LD Plus, Christ, Germany). Dried samples were ground in a ball mill with a tungsten carbide vial set (Model 8000M, Spex Sample Prep, USA) and stored in clean polyethylene vials inside a desiccator at room temperature. 

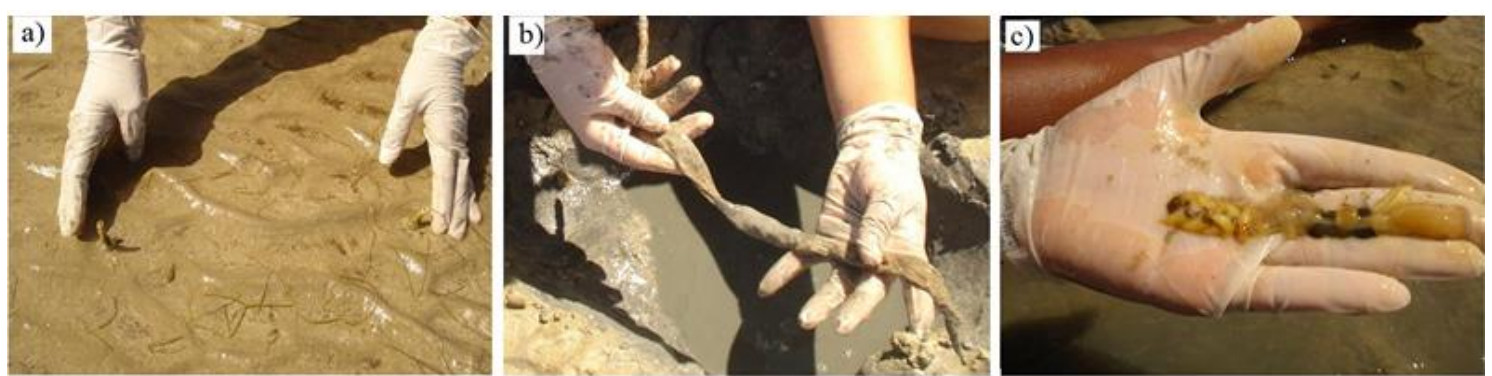

Figure 2. Sampling of (a) and (b) polychaete tube and (c) polychaete Chaetopterus variopedatus at the Todos os Santos Bay, Bahia

\subsection{Instrumentation}

Acid digestion of the samples was performed using a commercial high-pressure laboratory microwave oven (Milestone Ethos 1600 Microwave Labstation, Sorisole, Italy). This equipment was equipped with ten 100 $\mathrm{mL}$ tetrafluoromethoxy (TFM) tubes and operated at a frequency of $2,450 \mathrm{~Hz}$, with an energy output of $1,000 \mathrm{~W}$.

A quadrupole ICP-MS $X$ series II (Thermo, Germany) equipped with a hexapole collision cell (CC) was used for $\mathrm{As}, \mathrm{Ba}, \mathrm{Cd}, \mathrm{Co}, \mathrm{Cr}, \mathrm{Cu}$, $\mathrm{Hg}, \mathrm{Mn}, \mathrm{Ni}$ and $\mathrm{Sb}$ determinations. The elements $\mathrm{Ge}, \mathrm{Rh}, \mathrm{Tl}$, In and $\mathrm{Bi}$ were used as internal standards in sample solutions to compensate for any matrix effects and instrument drift. The instrument software allows for a rapid switch between standard mode (no gas, cell vented to mass analyzer chamber) to CC mode, whilst continuously aspirating the sample. The pre-mixed gases $\mathrm{H}_{2}(7 \%)$ in $\mathrm{He}\left(\mathrm{H}_{2} \mathrm{O}\right.$ and other impurities < 5 ppm) were admitted into the CC under flow control through stainless steel lines. The measurements were carried out with nickel sampler and skimmer cones $(1.0 \mathrm{~mm}$ and 0.7 $\mathrm{mm}$ diameter orifices) and a standard concentric nebulizer. A glass impact bead spray chamber cooled to $4{ }^{\circ} \mathrm{C}$ using a Peltier cooler and a shielded Fassel torch was used to minimize plasma potential and thereby obtain low and narrow initial ion energy distribution. The detector was operated in dual mode and cross-calibration was performed. Table 1 presents the ICP-MS operational conditions.

Table 1. Operating conditions for ICP-MS

\begin{tabular}{cc}
\hline Parameter & Conditions \\
\hline RF incident power & $1300 \mathrm{~W}$ \\
Plasma argon flow rate & $13 \mathrm{~L} \mathrm{~min}^{-1}$ \\
Auxiliary argon flow rate & $0.7 \mathrm{~L} \mathrm{~min}^{-1}$ \\
Nebulizer argon flow rate & $0.87 \mathrm{~L} \mathrm{~min}^{-1}$ \\
Scanning mode & Peak jump \\
Resolution & Standard \\
Dwell time & $10 \mathrm{~ms}$ \\
Sweeps & 100 \\
Number of readings per replicate & 3 \\
Daily perfomance & ${ }^{140} \mathrm{Ce}^{16} \mathrm{O}^{+} /{ }^{140} \mathrm{Ce} \mathrm{and}^{137} \mathrm{Ba}^{++} /{ }^{137} \mathrm{Ba}^{+}<2 \%$ \\
CCT gas flow & $6.5 \mathrm{~mL} \mathrm{~min}^{-1}$ \\
\hline
\end{tabular}

An ICP OES with axially viewed configuration (VISTA PRO, Varian, Mulgrave, Australia) equipped with solid state detector charge-coupled device (CCD), diffraction grating type echelle, cyclonic spray chamber, and concentric nebulizer was employed for $C$, 
$\mathrm{Mn}$ and $\mathrm{Cu}$ determination. The operating conditions are summarized in Table 2.

Table 2. Operating conditions for ICP OES

\begin{tabular}{lc}
\hline \multicolumn{1}{c}{ Parameter } & Conditions \\
\hline Generator of radio & $40 \mathrm{MHz}$ \\
frequency & $1300 \mathrm{~W}$ \\
RF incident power & $15 \mathrm{~L} \mathrm{~min}^{-1}$ \\
Plasma argon flow rate & $0.7 \mathrm{~L} \mathrm{~min}^{-1}$ \\
Nebulizer argon flow rate & $1.5 \mathrm{~L} \mathrm{~min}^{-1}$ \\
Auxiliary argon flow rate & V-Groove \\
Nebulizer type & Sturmann-Master \\
Spray chamber & $\mathrm{Cu} 327.395(\mathrm{I}=$ atomic line); Mn 257.610 (II = ionic line) \\
Emission lines $(\mathrm{nm})$ & \\
\hline
\end{tabular}

\subsection{Reagents and solutions}

All labware was soaked in a $\mathrm{HNO}_{3}$ acid bath $(65 \% \mathrm{w} / \mathrm{w}$, diluted $1 / 10$ with high purity water) for $24 \mathrm{~h}$ and rinsed with high purity water. Subsequently, all material was dried in a clean bench at ambient temperature. All solvents and reagents were of the highest commercially available purity.

High purity deionised water (resistivity 18.2 $\mathrm{M} \Omega \mathrm{cm}$; Millipore, Bedford, MA, USA) was employed to prepare all standards and sample solutions. Suprapur grade $\mathrm{HNO}_{3} 65 \%$ $(\mathrm{w} / \mathrm{w})$ and $\mathrm{H}_{2} \mathrm{O}_{2} \quad 30 \% \quad(\mathrm{w} / \mathrm{w})$ (Merck, Darmstadt, Germany) were used for sample digestion. Monoelemental, high-purity grade $1 \mathrm{~g} \mathrm{~L}^{-1}$ stock solutions of $\mathrm{As}, \mathrm{Ba}, \mathrm{Cd}, \mathrm{Cr}, \mathrm{Co}, \mathrm{Cu}$, $\mathrm{Hg}, \mathrm{Mn}, \mathrm{Ni}$ and $\mathrm{Sb}$ and multielement solution $100 \mathrm{mg} \mathrm{L}^{-1}$ of $\mathrm{Bi}, \mathrm{Ge}, \mathrm{In}, \mathrm{Tl}, \mathrm{Rh}$ and $\mathrm{Sc}$ were purchased from Merck (Darmstadt, Germany). Determination by ICP-MS was performed with external calibration using analytical solutions from 0.5 to $25 \mathrm{mg} \mathrm{L}^{-1}$. For this technique, the reference analytical solutions and the samples were adjusted to acid concentration of $0.288 \mathrm{~mol} \mathrm{~L}^{-1} \mathrm{HNO}_{3}$, as recommended by the manufacturer. Determination by ICP OES was performed with external calibration using analytical solutions ranging from $100-3,000 \mathrm{mg} \mathrm{L}^{-1}$ for $\mathrm{C}$ and $0.01-15 \mathrm{mg} \mathrm{L}^{-1}$ for $\mathrm{Cu}$ and $\mathrm{Mn}$. The reference analytical solutions and the samples were adjusted to acid concentration $<4 \mathrm{~mol} \mathrm{~L}^{-1} \mathrm{HNO}_{3}$.

\subsection{Optimization of sample digestion}

The optimization of sample weight and volume of acid was performed in triplicate. There is no certified reference material (CRM) for polychaete tissue, so all experiments were realized with the CRM Oyster Tissue (Oyster tissue - NIST 1566b National Institute of Standard and Technology, USA). In this study three experiments were performed in order to obtain the best conditions for the digestion of the samples.

In the first experiment, $100 \mathrm{mg}$ and 200 $\mathrm{mg}$ of CRM oyster tissue sample were used. The samples were weighed in microwave vessels, $7 \mathrm{~mL}$ of distilled nitric acid and 1.0 $\mathrm{mL}$ of $\mathrm{H}_{2} \mathrm{O}_{2} 30 \% \mathrm{v} / \mathrm{v}$ were also added to each vessel to test the mass size effect on the digestion. The digestion conditions were: power of $1,000 \mathrm{~W}$, temperature of $90^{\circ} \mathrm{C}$ and $180^{\circ} \mathrm{C}$ in the first and last stages, respectively (Table 3 ). In the experiment 2 , the mass of $200 \mathrm{mg}$ of CRM was digested with acid mixtures of different concentrations: 14.1, $12.1,10.1,8.1,6.1$ and $4.1 \mathrm{~mol} \mathrm{~L}^{-1}$. The power, time of each step and temperature were also modified. The objective of the 
experiment 2 was to verify the possibly of using a more dilute solution, in order to reduce the volume of residues generated, while still obtaining satisfactory recovery for analytes in the CRM. The experiment 3 was performed to assess the possibility of reducing digestion time under the digestion conditions using diluted acids. The time was reduced from 10 to $6 \mathrm{~min}$ in step 3 and the temperature was also reduced from $210^{\circ} \mathrm{C}$ (used in test 2) to $180^{\circ} \mathrm{C}$ in the last step of this test.

Table 3. Programs for digestion of CRM oyster (NIST 1566b) and polychaete tissues

\begin{tabular}{lcccc}
\hline & Step & Power $(\mathrm{W})$ & Time $(\mathrm{min})$ & Temperature $\left({ }^{\circ} \mathrm{C}\right)$ \\
\hline Experiment 1 & & & & \\
& 1 & 1000 & 4 & 90 \\
& 2 & 1000 & 2 & 90 \\
& 3 & 1000 & 8 & 180 \\
& 4 & 1000 & 20 & 180 \\
\hline Experiment 2 & & & & \\
& 1 & 500 & 5 & 120 \\
& 2 & 500 & 3 & 120 \\
& 3 & 1000 & 10 & 210 \\
& 4 & 1000 & 20 & 210 \\
\hline Experiment 3 & & & & \\
& 1 & 500 & 5 & 120 \\
& 2 & 500 & 3 & 120 \\
& 3 & 1000 & 6 & 180 \\
\hline
\end{tabular}

After digestion and cooling, the digests were transferred to LDPE flasks and made up to a final volume of $35.0 \mathrm{~mL}$ with ultrapure water. The digests were appropriately diluted, depending upon the concentration of the elements. Blanks were prepared in each batch of samples, using acid solution and $\mathrm{H}_{2} \mathrm{O}_{2} 30 \%$. After ensuring the best conditions for oyster tissues digestion, the digestion was applied to polychaete tissues.

2.5. Determination of the acidity and residual carbon content (RCC) of the digests

To determine the final acidity, acid-base titrations of the digests were performed. The titration was carried out with a standard solution of sodium hydroxide $\left(0.0997 \mathrm{~mol} \mathrm{~L}^{-1}\right.$, Merck, Germany) and phenolphthalein (1.0\% $\mathrm{m} / \mathrm{v}$ in ethanol). The residual carbon was determined by ICP OES, using the line emission for $C(I)$ at $193.025 \mathrm{~nm}$. Carbon reference solution used for external calibration RCC determination was prepared by dissolution of citric acid (Merck, Darmstadt, Germany) in water (25-500 mg $\mathrm{L}^{-1}$ of C). ${ }^{26}$

\subsection{Quality assurance and quality control}

All the samples were digested in triplicates. Element concentrations were calculated and expressed in $\mu \mathrm{g} \mathrm{g}^{-1}$ dry weight. Accuracy of analytical method was monitored by analyzing a CRM. At least one sample of the CRM and three blanks (reagents and digestion blanks) were included in each analytical batch. The precision of the method, defined as the closeness of agreement between mutually independent test results, was determined in terms of the percentage of the relative standard deviation (RSD \%).

There are no certified reference materials for polychaete tissue samples. Therefore, it was used two different procedures in order 
to validate the proposed method. Firstly, an oyster tissue certified reference material, containing most of the studied elements, was analyzed in triplicate using microwaveassisted digestion under selected optimum conditions. Secondly, the evaluation of the analytical performance of procedure was also made by a spike recovery study.

\section{Results and discussion}

\subsection{Techniques performance}

For ICP-MS, some of the studied elements suffer from polyatomic and isobaric interferences. This is the case for the $\mathrm{Cr}$ signal at $\mathrm{m} / \mathrm{z} 52$ by ${ }^{40} \mathrm{Ar}^{12} \mathrm{C}^{+}$and ${ }^{36} \mathrm{Ar}^{16} \mathrm{O}^{+}$, the $\mathrm{Cu}$ signal at $\mathrm{m} / \mathrm{z} 63$ by ${ }^{40} \mathrm{Ar}^{23} \mathrm{Na}^{+}$, the $\mathrm{Mn}$ signal at $\mathrm{m} / \mathrm{z} 55$ by ${ }^{40} \mathrm{Ar}^{15} \mathrm{~N}^{+}$, and the As signal at $\mathrm{m} / \mathrm{z} 75$ by ${ }^{40} \mathrm{Ar}^{35} \mathrm{Cl}$. Collision/reaction cell was used to remove or reduce many polyatomic species. The daily optimization procedure involved the $x y z$ alignment of the torch, determination of the optimum nebulizer gas flow rate and the ion lens voltage to maximize ${ }^{115} \mathrm{In}^{+}$signal and to obtain low oxide $\left({ }^{140} \mathrm{Ce}^{16} \mathrm{O}^{+} /{ }^{140} \mathrm{Ce}^{+}\right)$and double charged ions $\left({ }^{137} \mathrm{Ba}^{++} /{ }^{137} \mathrm{Ba}^{+}\right)$. The determination of $\mathrm{As}, \mathrm{Ba}, \mathrm{Cd}, \mathrm{Co}, \mathrm{Cr}, \mathrm{Cu}, \mathrm{Hg}$, $\mathrm{Mn}, \mathrm{Ni}$ and $\mathrm{Sb}$ were monitored in the standard (STD) and cell collision technology (CCT) modes, in the presence of premixed 7\% $\mathrm{H}_{2}$ in He gas. Considering the agreement with the certified values, the following conditions were selected for analysis from the experimental uncertainties: CCT mode for the determination of ${ }^{75} \mathrm{As},{ }^{59} \mathrm{Co},{ }^{52} \mathrm{Cr},{ }^{63} \mathrm{Cu},{ }^{55} \mathrm{Mn}$, and ${ }^{60} \mathrm{Ni}$; and STD mode for the determination of ${ }^{111} \mathrm{Cd},{ }^{121} \mathrm{Sb},{ }^{138} \mathrm{Ba}$ and ${ }^{201} \mathrm{Hg}$. For the quantification limit (LOQ), ten blanks were prepared and analysed. The result was multiplied for ten and divided for the angular coefficient of the analytical curve for each element. The LOQs obtained for ICP-MS were: As $\left(0.098 \mu \mathrm{g} \mathrm{g}^{-1}\right), \mathrm{Ba}\left(0.907 \mu \mathrm{g} \mathrm{g}^{-1}\right), \mathrm{Cd}$ $\left(0.080 \mu \mathrm{g} \mathrm{g}^{-1}\right), \mathrm{Cr}\left(0.695 \mu \mathrm{g} \mathrm{g}{ }^{-1}\right)$, Co $(0.233 \mu \mathrm{g}$ $\left.\mathrm{g}^{-1}\right), \mathrm{Cu}\left(0.465 \mu \mathrm{g} \mathrm{g}^{-1}\right), \mathrm{Hg}\left(0.819 \mu \mathrm{g} \mathrm{g}^{-1}\right), \mathrm{Mn}$ $\left(1.294 \mu \mathrm{g} \mathrm{g}^{-1}\right), \mathrm{Ni}\left(0.520 \mu \mathrm{g} \mathrm{g}^{-1}\right)$ and Sb (0.109 $\left.\mu \mathrm{g} \mathrm{g}^{-1}\right)$.

For ICP OES, since the signal intensities of each element depend on the sample matrix, it is important to optimize ICP OES parameters such as the radio-frequency (RF), incident power and nebulizer argon gas flow rate. The incident power and nebulizer gas flow-rate were optimized in the 1,000-1,400 $\mathrm{W}$ and $0.60-0.90 \mathrm{~L} \mathrm{~min}^{-1}$ ranges, respectively. The results showed that the greatest $\mathrm{Mg}(\mathrm{II}) / \mathrm{Mg}(\mathrm{I})$ ratio of 9.46 was obtained at 1,300 $\mathrm{W}$ incident power and 0.70

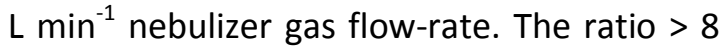
indicates that the conditions of plasma are robust. $^{36}$ These operational conditions were adopted throughout. The LOQ obtained for ICP OES were: $2.8 \mu \mathrm{g} \mathrm{g}^{-1}$ for $\mathrm{Cu}$ and $0.027 \mu \mathrm{g}$ $\mathrm{g}^{-1}$ for $\mathrm{Mn}$.

\subsection{Quality assurance and quality control}

The recoveries of spiked additions, made in polychaete samples prior digestions, ranged from of $85 \%$, for $\mathrm{Cu}$ at $200 \mathrm{ng} \mathrm{g}^{-1}$, to $110 \%$, for Ba at $100 \mathrm{ng} \mathrm{g}^{-1}$ (Table 4), with standard deviations $(n=3)$ lower than $6 \%$ in all cases. The recoveries obtained confirmed that the proposed procedure showed good analytical performance. 
Table 4. Recoveries (\%) for spiked polychaetas samples under optimized digestion conditions

\begin{tabular}{ccc}
\hline & \multicolumn{2}{c}{ Spike recovery (\%) } \\
Element & $100 \mathrm{ng} \mathrm{g}^{-1}$ & $200 \mathrm{ng} \mathrm{g}^{-1}$ \\
\hline${ }^{138} \mathrm{Ba}$ & 110 & 107 \\
${ }^{52} \mathrm{Cr}$ & 91 & 88 \\
${ }^{201} \mathrm{Hg}$ & 104 & 94 \\
${ }^{60} \mathrm{Ni}$ & 85 & 86 \\
${ }^{121} \mathrm{Sb}$ & 90 & 90 \\
\hline
\end{tabular}

\subsection{Optimization of the sample digestion procedure}

Sample digestion is a critical step in most analytical procedures for the routine determination of chemical elements in environmental samples. The use of nitric acid for organic matrix digestion is the most usual approach for wet sample pre-treatment to facilitate the determination of trace elements for atomic spectrometric methods. Ideal digestions should lead to the complete decomposition of the organic material using minimal amounts of acid. Acid solutions should be as diluted as possible in order to decrease residual carbon and final acid concentration. ${ }^{11}$ In the literature, there are various methods for the digestion of biological tissues using different reagents under specific conditions of $\mathrm{pH}$, time and temperature. Compared to other traditional methods, an advantage of using microwaveassisted digestion is the short time required. ${ }^{37,38}$ In this study, samples of 100 , 150 and $200 \mathrm{mg}$, were decomposed, in triplicate, in the experiment 1 . A mass of 200 $\mathrm{mg}$ was analised in experiments 2 and 3 , using diluted acid, in only $34 \mathrm{~min}$, which is a very important aspect for routine environmental analysis.

The efficiency of a microwave-assisted digestion is governed by three variables: acid concentration, digestion time and equipment power. In order to optimize digestion, various programs involving different temperatures $\left(180,200\right.$ and $\left.210^{\circ} \mathrm{C}\right)$ and times $(10$ and 20 min in the fourth step) were evaluated and the best results obtained were considered to be the most appropriate and therefore were finally selected (Table 5).

The applied microwave-assisted digestion procedure with the acid mixture of $8.1 \mathrm{~mol} \mathrm{~L}^{-1}$ in experiment 3 , resulted in solutions with low residual acidity and carbon contents (9.6 $\pm 0.80 \%$ ), which are important prerequisites for multielement determination using ICPMS. The use of diluted acids has several advantages, such as cost reduction, minimization of residues, reduction of blank values, and prevention of damages to equipment. $^{28,30,39-41}$ All digestion procedures were evaluated by comparing the residual carbon content, the residual acidity of digests and the trace element recoveries. The residual carbon contents ranged from $4.0 \pm$ $0.32 \%$ to $14.9 \pm 0.90 \%(n=3)$. According Nóbrega et $\mathrm{al}^{42}$ the digestion efficiency increases at higher temperature and power, reducing the RCC. In this study, however, it was not possible to increase the temperature above $220^{\circ} \mathrm{C}$ due to the maximum limit permitted by equipment microwave manufacturer. The residual acidity obtained after the digestions, as expected, was highest for the most concentrated solutions. Residual acidity of the diluted digests was 1.6 to 3.8 $\mathrm{mol} \mathrm{L}^{-1} \mathrm{HNO}_{3}$. 
Table 5. Recoveries (\%) of analytes obtained from the digestion procedures of CRM oyster tissue (1566b) for ICP-MS and ICP OES*, using various acid solution mixtures

\begin{tabular}{ccccccc}
\hline $\begin{array}{c}\text { Mass } \\
(\mathrm{mg})\end{array}$ & $\begin{array}{c}\text { Acid misture } \\
{[]_{\mathrm{mol} \mathrm{L}}^{-1}}\end{array}$ & As & Cd & Co & $\mathrm{Cu}$ & $\mathrm{Mn}$ \\
\hline $\begin{array}{c}\text { Experiment 1 } \\
100\end{array}$ & 14.1 & 114 & 87 & 85 & 84 & 169 \\
200 & 14.1 & 97 & 112 & 102 & 93 & 89 \\
$\begin{array}{c}\text { Experiment 2 } \\
200\end{array}$ & 14.1 & 91 & 87 & 82 & $85^{*}$ & $74^{*}$ \\
200 & 12.1 & 91 & 86 & 88 & $92^{*}$ & $90^{*}$ \\
200 & 10.1 & 91 & 86 & 84 & $92^{*}$ & $91^{*}$ \\
200 & 8.1 & 93 & 89 & 86 & $87^{*}$ & $86^{*}$ \\
200 & 6.1 & 100 & 95 & 94 & $83^{*}$ & $70^{*}$ \\
200 & 4.1 & 95 & 90 & 89 & $103^{*}$ & $64^{*}$ \\
Experiment 3 & & & & & & \\
200 & 10.1 & 95 & 91 & 86 & $87^{*}$ & $92^{*}$ \\
200 & 8.1 & 100 & 95 & 93 & $89 *$ & $102^{*}$ \\
\hline
\end{tabular}

3.4. Effect of the sample size on the efficiency of the microwave-assisted digestion process

After the removal of the polychaete intestines, the dry weight obtained for the biological tissue of each organism was, in general, below $200 \mathrm{mg}$. In order to have enough biological tissue mass for the experiments realized in this study, it was necessary to combine 15 individuals from each sampling site. Considering the size of the polychaetes, the effect of a sample mass on the digestion is critical, and it was evaluated. This means that attempts to work with only one individual polychaete to characterize and/or to monitor the contamination of a site will require the selection of only the largest individuals. The size of the polychaete, however, cannot be estimated by observing the extremities of the tube, above the sediments surface, as a result it is necessary to collect a number of tubes to choose organisms with adequate size, which is not very practical.

Many species of polychaetes are small. However, C. variopedatus have mass and size comparable to some marine invertebrates frequently used as biomonitors, such us clams and mussels. The sample mass for the digestion of polychaetes may also vary according to the species to be analyzed. ${ }^{43,44}$ The digestion conditions applied in experiment 1 , with acid mixture of $14.1 \mathrm{~mol}$ $\mathrm{L}^{-1}$, showed good results and high precision for the majority of the studied elements in sample mass of 150 and $200 \mathrm{mg}$. However, triplicate samples of $100 \mathrm{mg}$ produced very variable and discrepant results, suggesting that it is inappropriate to use such a small mass. Moreover, the $\mathrm{As}, \mathrm{Cu}, \mathrm{Cd}, \mathrm{Mn}$ and $\mathrm{Ni}$ concentrations obtained for $200 \mathrm{mg}$, were closest to the certified values that values obtained for $100 \mathrm{mg}$, possibly due to the higher sample homogeneity in $200 \mathrm{mg}$ samples. It is suggested that, for the polychaete species tested in this study, a minimum mass of $200 \mathrm{mg}$ should be used to obtain more representative and accurate results.

\subsection{Applications}

The proposed method has been applied for the determination of trace elements in $C$. variopedatus collected in five sites at Todos os Santos Bay, Bahia (Table 5). Although this is only a preliminary evaluation, since only a reduced set of sites were assessed, it is clear 
that concentrations were very variable both among elements and studied sites. The concentrations of $\mathrm{Hg}$ and $\mathrm{Sb}$ were $<\mathrm{LOQ}$ in all samples, except for $\mathrm{Hg}$ that was found in Itapagipe $\left(1.18 \pm 0.17 \mu \mathrm{g} \mathrm{g}^{-1}\right)$. This region is contaminated by $\mathrm{Hg}$ due to the production of chlorine and caustic soda, during 12 years on the shores of Itapagipe bay. ${ }^{45}$

The highest $\mathrm{As}$ and $\mathrm{Ni}$ concentrations were observed at Praia Grande and Bimbarras. An important petrochemical complex and harbor is located in front of Maré Island, where Praia Grande and Botelho are found. Both the harbor and the petrochemical complex among other industries in the region are well documented sources of several metals. ${ }^{5,41,46}$ High values of $\mathrm{Cd}$ in Bimbarras may be associated to intense port activity (mainly petrochemical products) at Madre de Deus Island and also the influence of the Subae estuary, which is the main source of contaminated particulate material to BTS. ${ }^{47}$

Arsenic levels in some polychaetes are generally high, and appear to be concentrated in lipids. ${ }^{48}$ Chaetopterus variopedatus can store up to 46,000 leg g $\mathrm{g}^{-1}$ of As in their tissue without being intoxicated. ${ }^{49}$ Arsenic concentrations in polychaete tissue are determined by a variety of factors including exposure, diet and the physiology of the organisms. ${ }^{50}$ In this work, the As concentrations in the polychaete tissues were higher than reported results for others polychaete species $^{51}$ and bivalves. ${ }^{5,52,53}$

Although the contents of some elements (i.e. $\mathrm{Cd}$ and $\mathrm{Ba}$ ) presented a large variability between sites, the concentrations of $\mathrm{Ba}, \mathrm{Ni}$, and $\mathrm{Cr}$ obtained in this study were, generally, smaller than the values reported in the literature for several species. ${ }^{49}$ However, $\mathrm{Cd}$ and $\mathrm{Cu}$ values were similar to the reported values in other polychaetes species. ${ }^{9,54}$

Between sampling points, the levels of $\mathrm{Co}$ were highest in Praia Grande. The $\mathrm{Ba}, \mathrm{Co}, \mathrm{Cd}$ and $\mathrm{Mn}$ concentrations obtained in this polychaete species were similar to the concentrations measured in shellfish of the Todos os Santos Bay. ${ }^{5}$ The highest $\mathrm{Mn}$ concentrations occurred at Botelho, which is possibly related to the anthropogenic introduction of this element by the industries and port activities at Aratu Bay. ${ }^{41}$ However natural background levels of $\mathrm{Mn}$ are relatively high at Todos os Santos Bay sediments $\left(344 \pm 105 \mathrm{mg} \mathrm{kg}^{-1}\right),{ }^{45}$ and may explain the concentrations observed at all other sites. Copper presented moderately high concentrations at all studied sites, with the exception of Bimbarras. To mention just a few, there are inputs of untreated sewage all around the bay and several industries and intense port activities that contribute to the Cu burden in the sediments and biota.

Table 6. Mean \pm standard deviation element concentrations ( $\mu \mathrm{g} \mathrm{g}^{-1}$, dry weight) in Chaetopterus variopedatus collected along Todos os Santos Bay, Bahia, Brazil

\begin{tabular}{cccccc}
\hline & Praia Grande $^{\mathrm{a}}$ & Praia Grande $^{\mathrm{b}}$ & Botelho & Itapagipe Bay & Bimbarras \\
\hline $\mathrm{As}$ & $145 \pm 4.78$ & $138 \pm 2.33$ & $89.2 \pm 2.48$ & $81.4 \pm 2.44$ & $133 \pm 2.48$ \\
$\mathrm{Ba}$ & $2.30 \pm 0.16$ & $2.25 \pm 0.09$ & $2.93 \pm 0.21$ & $1.00 \pm 0.02$ & $1.64 \pm 0.03$ \\
$\mathrm{Cd}$ & $0.40 \pm 0.02$ & $0.58 \pm 0.02$ & $0.59 \pm 0.03$ & $0.18 \pm 0.004$ & $2.04 \pm 0.028$ \\
$\mathrm{Cr}$ & $1.02 \pm 0.03$ & $1.07 \pm 0.05$ & $1.15 \pm 0.02$ & $<\mathrm{LOQ}$ & $0.44 \pm 0.03$ \\
$\mathrm{Co}$ & $9.23 \pm 0.36$ & $10.6 \pm 0.38$ & $3.53 \pm 0.27$ & $4.35 \pm 0.44$ & $2.52 \pm 0.03$ \\
$\mathrm{Cu}$ & $7.76 \pm 0.38$ & $8.49 \pm 0.27$ & $8.35 \pm 0.35$ & $6.49 \pm 0.54$ & $2.38 \pm 0.05$ \\
$\mathrm{Hg}$ & $<\mathrm{LOQ}$ & $<\mathrm{LOQ}$ & $<\mathrm{LOQ}$ & $1.18 \pm 0.17$ & $<\mathrm{LOQ}$ \\
$\mathrm{Mn}$ & $27.9 \pm 0.93$ & $35.5 \pm 2.25$ & $50.6 \pm 1.67$ & $33.9 \pm 1.01$ & $30.8 \pm 0.49$ \\
$\mathrm{Ni}$ & $3.50 \pm 0.13$ & $3.50 \pm 0.06$ & $1.74 \pm 0.08$ & $1.13 \pm 0.10$ & $3.18 \pm 0.07$ \\
$\mathrm{Sb}$ & $<\mathrm{LOQ}$ & $<\mathrm{LOQ}$ & $<\mathrm{LOQ}$ & $<\mathrm{LOQ}$ & $<\mathrm{LOQ}$ \\
\hline
\end{tabular}

${ }^{\mathrm{a}}$ March 2010; ${ }^{\mathrm{b}}$ October 2010 
Evaluating the scientific literature, the use of polychaetes, as a biomonitor, is much less than oysters, mussels and clams, suggesting that the potential use of these organisms is yet to be explored. Moreover, once this polychaete lives in physical and chemical conditions (e.g. substrate type, grain size of sediments, dissolved oxygen and organic matter concentrations) different from those observed for oyster and/or mussels, the data obtained for this organism complement the results of other biomonitor organisms in monitoring programs. The use of various organisms in monitoring programs provides information of the relative importance of bioavailable metal sources. ${ }^{55}$

\section{Conclusions}

The proposed procedure is suitable for decomposition of polychaete samples $C$. variopedatus for subsequent trace elements (As, Ba, Cd, Cr, Co, Cu, Hg, $\mathrm{Mn}, \mathrm{Ni}$ and $\mathrm{Sb}$ ) determination by ICP-MS or ICP OES. Repeatability was satisfactory $(<10 \%)$ and results for CRM agreed well with the certified values. The obtained RCC values were lower than $15 \%$, which is important for minimizing the generation of residues and improving detection limits. Moreover, up to ten samples can be simultaneously decomposed in 34 min, resulting in a high sample throughput that is an essential aspect for routine environmental analysis. The polychaete species studied showed sufficient mass for chemical analysis and accumulation of trace metals, especially As. The use of this species should be better explored as a biomonitor species for monitoring programs.

\section{Acknowledgments}

The authors are grateful to Fundação de Amparo à Pesquisa do Estado da Bahia (FAPESB), Conselho Nacional de Desenvolvimento Científico e Tecnológico
(CNPq), Coordenação de Aperfeiçoamento de Pessoal de Nível Superior (CAPES) and Petróleo Brasileiro S. A. for providing grants and fellowships.

\section{References}

${ }^{1}$ Yebra-Biurrun, M. C.; Garcia-Garrido, A. Continuous flow systems for the determination of trace elements and metals in seafood. Food Chemistry 2001, 72, 279. [CrossRef]

${ }^{2}$ Rainbow, P. S. Trace metal concentrations in aquatic invertebrates: why and so what? Environmental Pollution 2002, 120, 497. [CrossRef]

${ }^{3}$ Turkmen, M.; Ciminli, C. Determination of metals in fish and mussel species by inductively coupled plasma-atomic emission spectrometry. Food Chemistry 2007, 103, 670. [CrossRef]

${ }^{4}$ Luoma, S. N.; Rainbow, P. S.; Metal Contamination in Aquatic Environments: Science and Lateral Management: Cambridge University Press, 2008.

${ }^{5}$ Souza, M. M.; Windmöller, C. C.; Hatje, V. Shellfish from Todos os Santos Bay, Bahia, Brazil: Treat or threat?. Marine Pollution Bulletin 2011, 62, 2254. [CrossRef]

${ }^{6}$ Saiz-Salinas, J. I.; Francés-Zubillaga, G. Nereis diversicolor: an Unreliable Biomonitor of Metal Contamination in the 'Ría de Bilbao' (Spain). Marine Ecology 1997, 18, 113. [CrossRef]

${ }^{7}$ Casado-Martinez, M. C.; Smith, B. D.; Luoma, S. N.; Rainbow, P. S. Metal toxicity in a sediment-dwelling polychaete: Threshold body concentrations or overwhelming accumulation rates?. Environmental Pollution 2010, 158, 3071. [CrossRef]

${ }^{8}$ Waring, J. S.; Maher, W. A.; Krikowa, F. Trace metal bioaccumulation in eight common coastal Australian polychaeta. Journal of Environmental Monitoring 2006, 8, 1149. [CrossRef]

${ }^{9}$ Garcês, J.; Costa, M. H. Trace metals in populations of Marphysa sanguínea (Montagu, 1813) from Sado estuary: effect of 
body size on accumulation. Scientia Marina 2009, 73, 605. [CrossRef]

10 Fattorini, D.; Notti, A.; Nigro, M.; Regoli, F. Hyperaccumulation of vanadium in the Antarctic polychaete Perkinsiana littoralis as a natural chemical defense against predation. Environmental Science and Pollution Research 2010, 17, 220. [CrossRef]

${ }^{11}$ Arruda, M. A. Z.; Trends in Sample Preparation. Nova Science Publishers: New York, 2007

12 Korn, M. G. A.; Castro, Jacira Teixeira; Barbosa, J. T. P.; Morte, E. S. B.; Teixeira, A. P.; Welz, Santos, W. P. C.; Fernandes, A. P.; Santos, E. B. G. N.; Korn, M. Sample Preparation for the Determination of Metals in Food Samples Using Spectroanalytical Methods-A Review. Applied Spectroscopy Reviews 2008, 43, 67. [CrossRef]

${ }^{13}$ Costa, L. M.; Santos, D. C. M. B.; Hatje, V.; Nóbrega, J. A.; Korn, M. G. A. Focusedmicrowave-assisted acid digestion: Evaluation of losses of volatile elements in marine invertebrate samples. Journal of Food Composition and Analysis 2009, 22, 238. [CrossRef]

14 Mouneyrac, C.; Mastain, O.; Amiard, J. C.; Amiard-Triquet, C.; Beaunier, P.; Smith, A. Y. B. D.; Rainbown, P. S. Trace-metal detoxification and tolerance of the estuarine worm Hediste diversicolor chronically exposed in their environment. Marine Biology 2003, 143, 731. [CrossRef]

15 Nesto, N.; Romano, S.; Moschino, V.; Mauri, M. Ros, L. D. Bioaccumulation and biomarker responses of trace metals and micro-organic pollutants in mussels and fish from the Lagoon of Venice, Italy. Marine Pollution Bulletin 2007, 55, 469. [CrossRef]

${ }^{16}$ Santos, W. P. C.; Hatje, V.; Lima, L. N.; Trignano, S. V.; Barros, F.; Castro, J. T.; Korn, M. G. A. Evaluation of sample preparation (grinding and sieving) of bivalves, coffee and cowpea beans for multi-element analysis. Microchemical Journal 2008, 89, 123. [CrossRef]

${ }^{17}$ García-Rico, L.; Tejeda-Valenzuela, L.; Burgos-Hernández, A. Seasonal Variations in the Concentrations of Metals in Crassostrea corteziensis from Sonora, México. Bulletin of
Environmental Contamination and Toxicology 2010, 85, 209. [CrossRef]

18 Osuna-Martínez, C.C.; Páez-Osuna, F.; Alonso-Rodríguez, R. A. Mercury in Cultured Oysters (Crassostrea gigas Thunberg, 1793 and C. corteziensis Hertlein, 1951) from Four Coastal Lagoons of the SE Gulf of California, Mexico. Bulletin of Environmental Contamination and Toxicology 2010, 85, 339. [CrossRef]

${ }^{19}$ Manutsewee, N.; Aeungmaitrepirom, W.; Varanusupakul, $\mathrm{P}$.; Imyim, A. Determination of $\mathrm{Cd}, \mathrm{Cu}$, and $\mathrm{Zn}$ in fish and mussel by AAS after ultrasound-assisted acid leaching extraction. Food Chemistry 2007, 101, 817. [CrossRef]

${ }^{20}$ Araújo, G. C. L.; Gonzalez, M. H.; Ferreira, A. G.; Nogueira, A. R. A.; Nóbrega, J. A. Effect of acid concentration on closed-vessel microwave-assisted digestion of plant materials. Spectrochimica Acta Part B: Atomic Spectroscopy 2002, 57, 2121. [CrossRef]

${ }^{21}$ Seco-Gesto, E.M.; Moreda-Pineiro, A.; Bermejo-Barrera, A.; Bermejo-Barrera, P. Multi-element determination in raft mussels by fast microwave-assisted acid leaching and inductively coupled plasma-optical emission spectrometry. Talanta 2007, 72, 1178. [CrossRef]

${ }^{22}$ Armenta, S.; Garrigues, S.; La Guardia, M. Green Analytical Chemistry. TrAC Trends in Analytical Chemistry 2008, 27, 497. [CrossRef]

${ }^{23}$ Reis, P. A.; Almeida, C. M. R. Matrix importance in animal material pre-treatment for metal determination. Food Chemistry 2008, 107, 1294. [CrossRef]

${ }^{24}$ Navarro, P.; Arana, G.; Etxebarria, N.; Dean, J. R. Evaluation of the physiologically based extraction test as an indicator of metal toxicity in mussel tissue. Analytica Chimica Acta 2008, 622, 126. [CrossRef]

${ }^{25}$ Castro, J. T.; Santos, E. C.; Santos, W. P. C.; Costa, L. M.; Korn, M.; Nóbrega, J. A.; Korn, M. G. A. A critical evaluation of digestion procedures for coffee samples using diluted nitric acid in closed vessels for inductively coupled plasma optical emission spectrometry. Talanta 2009, 78, 1378. [CrossRef] 
${ }^{26}$ Bizzi, C. A.; Flores, E. M. M.; Picoloto, R. S.; Barinb, J. S.; Nobrega, J. A. Microwaveassisted digestion in closed vessels: effect of pressurization with oxygen on digestion process with diluted nitric acid. Analytical Methods 2010, 2, 734. [CrossRef]

27 Bizzi, C. A.; Barin, J. S.; Garcia, E. E.; Nóbrega, J. A.; Dressler, V. L.; Flores, E. M. M. Improvement of microwave-assisted digestion of milk powder with diluted nitric acid using oxygen as auxiliary reagent. Spectrochimica Acta Part B: Atomic Spectroscopy 2011, 66, 394. [CrossRef]

28 Bizzi, C. A.; Barin, J. S.; Müller, E. I.; Shimidit, L; Nóbrega, J. A.; Flores, E. M. M. Evaluation of oxygen pressurized microwaveassisted digestion of botanical materials using diluted nitric acid. Talanta 2011, 83, 1324. [CrossRef]

${ }^{29}$ Gonzalez, M. H.; Souza, G. B.; Oliveira, P. V.; Forato, L. A.; Nóbrega, J. A.; Nogueira, A. R. A. Microwave-assisted digestion procedures for biological samples with diluted nitric acid: Identification of reaction products. Talanta 2009, 79, 396. [CrossRef]

${ }^{30}$ Bizzi, C. A.; Flores, E. M. M.; Barin, J. S.; Garcia, E. E.; Nobrega, J. A. Understanding the process of microwave-assisted digestion combining diluted nitric acid and oxygen as auxiliary reagent. Microchemical Journal 2011c, 99, 193. [CrossRef]

${ }^{31}$ Talbot, V., Chegwidden, A. Cadmium and other heavy metal concentrations in selected biota from Cockburn Sound, Western Australia. Australian Journal of Marine and Freshwater Research 1982, 33, 779. [CrossRef]

32 Macginitie, G. E. The method of feeding of tunicates. Biological Bulletin 1939, 77, 443. [CrossRef]

${ }^{33}$ Schaffner, L. C. Small-scale organismo distributions and patterns of species diversity: evidence for positive interactions in an estuarine benthic community. Marine Ecology Progress Series 1990, 61, 107. [CrossRef]

${ }^{34}$ Morgado, E. H.; Amaral, A. C. Z. Anelídeos poliquetos da região de Ubatuba (SP) padrões de distribuição geográfica. Revista Brasileira de Zoologia 1989, 6, 535. [CrossRef]
${ }^{35}$ Cirano, M.; Lessa, G. C. Oceanographic characteristics of Baía de Todos os Santos, Brazil. Revista Brasileira de Geofísica 2007, 25, 363. [CrossRef]

${ }^{36}$ Brenner, I. B.; Zander, A. T. Axially and radially viewed inductively coupled plasmas a critical review. Spectrochimica Acta Part B: Atomic Spectroscopy 2000, 55, 1195. [CrossRef]

${ }^{37}$ Singh, R. K., Chavan, S. L., Sapkale, P. H. Heavy Metal Concentrations in Water, Sediments and Body Tissues of Red Worm (Tubifex spp.) Collected from Natural Habitats in Mumbai, India. Environmental Monitoring and Assessment 2007, 129, 471. [CrossRef]

${ }^{38}$ Silva, E. G. P.; Hatje, V.; Santos, W. N. L.; Costa, L. M.; Nogueira, A. R. A.; Ferreira, S. L. C. Fast method for the determination of copper, manganese and iron in seafood samples. Journal of Food Composition and Analysis 2008, 21, 259. [CrossRef]

39 D'llio, S.; Violante, N.; Majorani, C.; Petrucci, F. Dynamic reaction cell ICP-MS for determination of total $\mathrm{As}, \mathrm{Cr}$, Se and $\mathrm{V}$ in complex matrices: Still a challenge? A review. Analytica Chimica Acta 2011, 698, 6. [CrossRef]

${ }^{40}$ Donati, G. L.; Amais, R. S.; Nóbrega, J. A. Strategies to improve accuracy and sensitivity in phosphorus determinations by inductively coupled plasma quadrupole mass spectrometry. Journal of the Brazilian Chemical Society, 2012, 23, 786. [CrossRef]

${ }^{41}$ Hatje, V.; Bícego, M. C.; Carvalho, G. C.; de Andrade, J. B.; Em Baía de Todos os Santos: aspectos oceanográficos; Hatje, V.; de Andrade, J. B., eds.; Edufba: Salvador, 2009, cap. 7.

42 Nóbrega, J. A.; Pirola, C.; Fialho, L. L.; Rota, G.; de Campo Jordão, C. E. K. M. A.; Pollo, F. Microwave-assisted digestion of organic samples: How simple can it become? Talanta 2012, 98, 272. [CrossRef]

${ }^{43}$ Solé, M.; Kopecka-Pilarczyk, J.; Blasco, J. Pollution biomarkers in two estuarine invertebrates, Nereis diversicolor and Scrobicularia plana, from a Marsh ecosystem in SW Spain. Environment International 2009, 35, 523. [CrossRef] 
${ }^{44}$ Pradit, S.; Wattayakorn, G.; Angsupanic, S.; Baeyens, W.; Leermakers, M. Distribution of Trace Elements in Sediments and Biota of Songkhla Lake, Southern Thailand. Water, Air, and Soil Pollution 2010, 206, 155. [CrossRef]

${ }^{45}$ CRA, Diagnóstico da concentração de metais pesados e hidrocarbonetos de petróleo nos sedimentos e biota da Baía de Todos os Santos. Consórcio BTS Hydros CH2MHILL. Governo do Estado da Bahia, 2004.

${ }^{46}$ Hatje, V.; Macedo, S. M.; De Jesus, R. M.; Cotrim, G.; Garcia, K. S.; Queiroz, A. F.; Ferreira, S. L. C. Inorganic As speciation and bioavailability in estuarine sediments of Todos os Santos Bay, BA, Brazil. Marine Pollution Bulletin 2010, 60, 2225. [CrossRef]

${ }^{47}$ Hatje, V.; Barros, F. Overview of the 20th century impact of trace metal contamination in the estuaries of Todos os Santos Bay: Past, present and future scenarios. Marine Pollution Bulletin 2012, 64, 2603. [CrossRef] ${ }^{48}$ Notti, A.; Fattorini, D.; Razzetti, E. M.; Regoli, F. Bioaccumulation and biotransformation of arsenic in the Mediterranean polychaete Sabella spallanzanii experimental observations. Environmental Toxicology and Chemistry 2007, 26, 1186. [CrossRef]

${ }^{49}$ Eisler, R. Compendium of trace metals and marine biota. Vol. Plants and invertebrates. Elsevier: Oxford, UK, 2010.

${ }^{50}$ Price, A.,; Maher, W.; Kirby, J.; Krikowa, F.; Duncan, E.; Taylor, A.; Potts, J. Distribution of arsenic species in an open seagrass ecosystem: relationship to trophic groups, habitats and feeding zones. Environmental Chemistry 2012, 9, 77. [CrossRef]

${ }^{51}$ Alam, M. A.; Gomes, A.; Sarkar, S. K.; Shuvaeva, O. V.; Vishnevetskaya, N. S.; Gustaytis, M. A.; Bhattacharya, B. D.; Godhantaraman, N. S. Trace Metal Bioaccumulation by Soft-bottom Polychaetes (Annelida) of Sundarban Mangrove Wetland, India and Their Potential Use as Contamination Indicator. Bulletin of Environmental Contamination and Toxicology 2010, 85, 492. [CrossRef]

52 Usero, J.; Morillo, J.; Gracia, I. Heavy metal concentrations in molluscs from the Atlantic coast of southern Spain. Chemosphere 2005, 59, 1175. [CrossRef]

${ }^{53}$ Volety, A. K. Effects of salinity, heavy metals and pesticides on health and physiology of oysters in the Caloosahatchee Estuary, Florida. Ecotoxicology 2008, 17, 579. [CrossRef]

${ }^{54}$ Davydkova, I. L.; Fadeeva, N. P.; Kovekovdova, L. T.; Fadeev, V. I. Heavy Metal Contents in Tissues of Dominant Species of the Benthos and in Bottom Sediments of Zolotoi Rog Bay, Sea of Japan. Russian Journal of Marine Biology 2005, 31, 176. [CrossRef] ${ }^{55}$ Eça, G. F.; Pedreira, R. M. A.; Hatje, V. Trace and major elements distribution and transfer within a benthic system: Polychaete Chaetopterus variopedatus, commensal crab Polyonyx gibbesi, worm tube, and sediments. Marine Pollution Bulletin 2013, 74, 32. [CrossRef] 